\title{
A new lean Six Sigma hybrid method based on the combination of PDCA and the DMAIC to improve process performance: Application to clothing SME
}

\author{
DOI: 10.35530/IT.070.05.1595
}

\section{ABSTRACT - REZUMAT}

\section{A new Lean Six Sigma hybrid method based on the combination of PDCA and the DMAIC to improve} process performance: Application to clothing SME

\begin{abstract}
This paper proposes a new Lean Six Sigma (LSS) methodology to improve process for clothing small- and medium-sized enterprise SME. The methodology is based on combination of two approaches which are the PDCA (Plan, Do, Check, and Act) and the DMAIC (Define, Measure, Analyze, Improve, and Control). The combination technique consists in applying the PDCA to continuously improve and control every DMAIC steps. The DMAIC approach has included Lean Six Sigma tools and techniques, as well as the success factors obtained from a survey, to improve its efficiency. The proposed approach is applied to improve the performances indicators such as Z sigma, Cp, cycle time, and lead time for the case of clothing SME in Tunisia. As an example, the Z-sigma has increased from the sigma level was improved from 1.45 to 3.85. The process capability $\mathrm{Cp}$ from 0.5 to 1.3 and the lead time was decreased from 39.47 days to 30.23 days. Finally, the study is concluded by sorting out the effects of the type of produced articles and the presence or not of the quality certification on the application of the proposed approach. The effectives from using PDCADMAIC technique are better when it's applied with certified company, than non-certified one.
\end{abstract}

Keywords: Lean Six Sigma, DMAIC, PDCA, framework, clothing SMEs

\section{O nouă metodă hibrid Lean Six Sigma bazată pe combinația PDCA și DMAIC pentru îmbunătățirea} performanței proceselor: aplicabilitate în IMM-urile producătoare de îmbrăcăminte

Acest studiu propune o nouă metodologie Lean Six Sigma (LSS) pentru îmbunătățirea proceselor de realizare a articolelor de îmbrăcăminte în companiile mici și mijlocii. Metodologia se bazează pe combinarea a două abordări și anume PDCA (Plan, Do, Check, Act) și DMAIC (Define, Measure, Analyze, Improve, Control). Tehnica de combinare constă în aplicarea PDCA pentru îmbunătățirea și controlul continuu ale fiecărei etape a DMAIC. Abordarea DMAIC a inclus instrumentele și tehnicile Lean Six Sigma, precum și factorii de succes, pentru îmbunătățirea eficienței acestuia. Abordarea propusă este aplicată pentru a îmbunătăți indicatorii de performanță, cum ar fi Z sigma, Cp, timpul ciclului și timpul de pregătire pentru IMM-urile producătoare de îmbrăcăminte din Tunisia. Ca exemplu, Z-sigma a crescut de la nivelul sigma, fiind îmbunătățit de la 1,45 la 3,85. Capacitatea procesului, Cp, a crescut de la 0,5 la 1,3 și timpul de pregătire a fost redus de la 39,47 zile la 30,23 zile. În cele din urmă, studiul a fost încheiat prin analiza influenţei tipului de articole produse și certificarea calităţii asupra aplicării metodei. Efectele utilizării tehnicii PDCA-DMAIC sunt mai bune atunci când se aplică la o companie certificată, decât în cazul unei companii necertificate.

Cuvinte-cheie: Lean Six Sigma, DMAIC, PDCA, cadru, IMM-uri producătoare de îmbrăcăminte

\section{INTRODUCTION}

The Lean Six Sigma method is one famous classical approach and it's considered among the most effective business improvement methodology [1]. It is simply a combination of the Lean and Six Sigma. Lean and Six Sigma are complementary methodology [2], and provide a powerful approach when combined. Lean helps to maximize value by improving quality and reducing the source of process shift, whereas Six Sigma helps to reduce source of process variation. Six Sigma reports major root causes to a problem [3]. It has changed over time from a metric to a business strategy [4-5], or to a management strategy [6-7], combined into the culture of the enterprise. This method is widely used in manufacturing firms in the world and is applied in different industrial fields, that include manufacturing [8-12], services [13-14], commercial [15], health care [16] and logistics [17]. The Six Sigma has two continuous models: Design for Six Sigma (DFSS) or Define, Measure, Analyze, Improve Control, (DMAIC). The second model is suitable for the implementation of an existing process. According to [18], if you cannot define your process, you cannot measure, improve and sustain the quality. While DMAIC is used when a product or process is already in existence but performing inadequately, a popular framework for Six Sigma implementation uses DMAIC methodology. Khaled Mili and Tarek Sadraoui use Six Sigma to solve the Straddle carrier routing Problem [19]. Few studies have been reported about the application of Lean Six Sigma in smalland medium-sized enterprises (SMEs) because of several problems [12]. A number of these have focused on barriers and the critical success factors 
in the implementation of Lean, Six Sigma, or LSS approaches [10, 21]. Other studies have focused on roadmaps for implementing LSS in Textile SME. Korthi et al. were integrated model of Lean Six Sigma and ISO 9001:2008 standard based QMS, L6QMS2008 model in a textile mill and thereby achieving annual savings of 2 million INR [22]. In addition the literature on LSS and its application in small- and medium-sized SME textile and apparel industries businesses is limited [23]. Some authors [24] identify the appropriate Lean principles for implementation in textile industry. A case study is carried out in a linen Fabrics industry by [25] using the DMAIC methodology to reduce the shade variations. Lean Six Sigma application still not known and it's limited for large Tunisian SMEs. Tarek Sadraoui et al., propose a new practice of Six Sigma for reduction of the number of conformities and minimization of the number of customers' Complaints for KITAMEUBLE industry in Tunisia [26]. The use of the complex tools remains difficult for small- and medium-sized enterprises (SME) because it requires an adapted model to successfully implement the approach and currently faces tremendous challenges and disruptive changes, triggered by new and capital intensive technologies [27]. In order to ensure the improvement of projects, LSS utilizes the Define, Measure, Analyze, Improve, Control (DMAIC) approach [28-29], integrating lean tools into a standard Six Sigma DMAIC cycle. According to [30] and [31] the systematic implementation of this approach makes the LSS application very effective. For this reasons, we can find many LSS implementation frameworks which are based on DMAIC, to drive the improvements [32-33]. Vijaya Sunder M. presents the importance for instilling process improvement culture, especially in LSS deployment and demonstrates how LSS project management can bring significant change in a retail bank [14]. Authors such as [31-32, 9], have proposed specific Six Sigma and LSS implementation frameworks, based on DMAIC, to drive the improvement of specific processes. In other studies, DMAIC approach has been applied, with specific tools in every stage [34-35, 9]. Tools such as Value Steam Mapping, Total Productive Maintenance (TPM), DoE, SPC, 5S and QFD are still a key to LSS implementation success [36].

Some authors [37] proposes a new LSS Framework based on the integration of the DMAIC cycle at each point in the Lean thinking cycle. One issue of this method is that the predominance given to the Six Sigma DMAIC cycle within the existing LSS framework can make Lean viewed and utilized as a tool kit of techniques, and removes the opportunity to use Lean as a strategic thinking approach within the LSS framework. This can drive quality-based improvement projects rather than Lean-based projects or projects that create a dual impact of both quality and efficiency improvement. Everton et al. identify and analyze the difference and the complementariness in the production areas for three models, Lean Six Sigma and Lean Six Sigma [38]. S. Karthi and S.R.
Devadasan integrate Lean Six Sigma, and ISO 9001: 2008 standard based Quality Management System, as a single framework benefiting contemporary organization [39]. A few numbers of academic studies in manufacturing have been done on it despite the existence of LSS for a while [36].

A few Six Sigma and LSS studies of SMEs have been done over time. The result of the pilot survey presented in the work of Antony 2007 in UK manufacturing SMEs, which is primarily based on descriptive statistics, shows that many of the SMEs are not aware of Six Sigma. For its successful implementation in SME, management involvement and participation, and linking Six Sigma to customers and to business strategy are the most critical factors for the successful deployment of Six Sigma in SMEs [39]. The result of the survey in our study in Tunisian Clothing SME shows that: The involvement and commitment of top management Performance measurement and communication are the most critical factors for the successful deployment of Six Sigma in these SMEs [40]. In the same context, Taner (2012) surveyed textile SMEs in Turkey and found that lack of knowledge about Six Sigma was the key reason why most SMEs were not implementing Six Sigma [41]. That's way, the hybrid approach which is based in the use of more than one technique have been introduced to overcome the limitation of classical approaches. As stated before, there are two different hybrid approaches which are given in the literature. Combining or integration approach between PDCA, as most effective tool, and the DMAIC as one model of the Six Sigma, starts to be a common technique to improve the systems performances in the last few years. In the following, these approaches are reviewed and analyze. In general, we distinguish two main techniques. In the first one, the DMAIC is applied for each PDCA steps. We called it DMAICapplied-to-PDCA. In the second technique, there is a similar relationship between DMAIC and PDCA, in other terms, every step in the DMAIC find an equivalent in PDCA steps; we called it DMAIC-similar-toPDCA.

The principal of the first technique consists in applying the DMAIC technique to the PDCA cycle. Every single steps of the PDCA is subjected to be controlled by all over the DMAIC cycle in order to improve the standard implementation, as well as the process [42]. The second technique is based on the similarity in the principals of PDCA and the DMAIC. In other terms, there is equivalence between every singles steps or more from the DMAIC and the PDCA steps. For example the equivalent of Plan is Define; the equivalent of Do is Measure... In this approach, the PDCA is the main player that influences the performance of the DMAIC and not the opposite as in the first one. The advantage of this approach is to relate Six Sigma initiative to PDCA cycle in order to ensure the comprehensive micro and macro within an organization [43]. 
Although that these hybrid methods bring some advanced comparing to the classical ones, they still present some limitations and drawbacks which are:

- Even that the first approach to be effective according to his others, its principal seems to be not logic and reasonable. This is because the PDCA by its nature as a helpful procedure could not be subjected to the DMAIC approach, but the opposite. In fact it's the PDCA which should be used to improve the DMAIC. Every approach, which is being introduced into an organization, can be checked against the PDCA cycle, which proves our idea.

- The second limitation is that the given study presents lack of implementation in real word applications, which reduce the effectiveness of the presented methods.

- In the second approach, we think that improving one or more steps of the DMAIC using only one step of the PDCA is not sufficient to improve all the process. This because every DMAIC step can be seen as a complete process from the side of the PDCA.

The main contributions of this work are:

- To develop a novel methodology based on the integration of two approaches PDCA and DMAIC, in order to improve the system efficiency and ensure the continuous improvements.

- To review and analyze the existing approaches used in process improvements systems.

- To apply the developed approach on one certified Tunisian clothing SME producing technical articles and compare the obtained results with other noncertified one producing Denim articles.

\section{MATERIAL AND METHOD}

This article presents a study on deployment of LSS framework in Tunisian clothing SME. The developed framework is based on the integration between DMAIC approach and PDCA cycle. The framework incorporates the tools, techniques and the critical success factors (CSFs) of LSS application, which are determined by a survey in a sample of well studies clothing SMEs, to be applied for each DMAIC steps. We think that a new methodology has to be introduced in order to solve the discussed issues. This methodology is basically the opposite of the DMAICapplied-to-PDCA because it's more effective that every step to be subjected to all the PDAC cycle. The principal of the proposed approach is basically the opposite of the DMAIC-applied-to- PDCA, so that, we called it PDCA-applied-to-DMAIC. The principal is described by figure 1. The established framework PDCA is applied to each DMAIC steps to improve continuously the process, focusing on continuous learning and knowledge creation. The PDCA (PlanDo-Check-Act), cycle is the basic procedure of TQM. It is more than quality tool but also is a fundamental approach of continuous improvement. In fact, it was considered as a well-established framework for process improvement where it focuses on continuous learning and knowledge creation. We choice the
PDCA cycle because it adds the rigor of project lifecycle (PLC) to the implementation and close-out of Lean Six Sigma projects. Every approach, which is being introduced into an organization, can be checked against the PDCA cycle, as follows: The 'Plan' phase allows verifying that applied approaches are well integrated and focused on the all needs. The 'Do' phase aims to check the systematic implementation of these approaches and the existence of appropriate measurement tools. In the 'Check' and 'Act' phases, we can check that these approaches are measured and improved. While Lean six sigma projects in companies can be adhered to a system that ensures continuous improvement such as PDCA. We believe framing Six Sigma projects within a PDCA cycle provides a more comprehensive view of Six Sigma implementation in clothing SMEs. In this section, the developed methodology, to come out with a LSS model in order to improve the quality and the production in clothing SME, is presented. This model is applied for the case study of tow clothing SMEs to: (1) Achieve a higher quality; (2) Increase process speed; (3) Reduce waste and (4) Increase Customer satisfaction. Every step is detailed below.

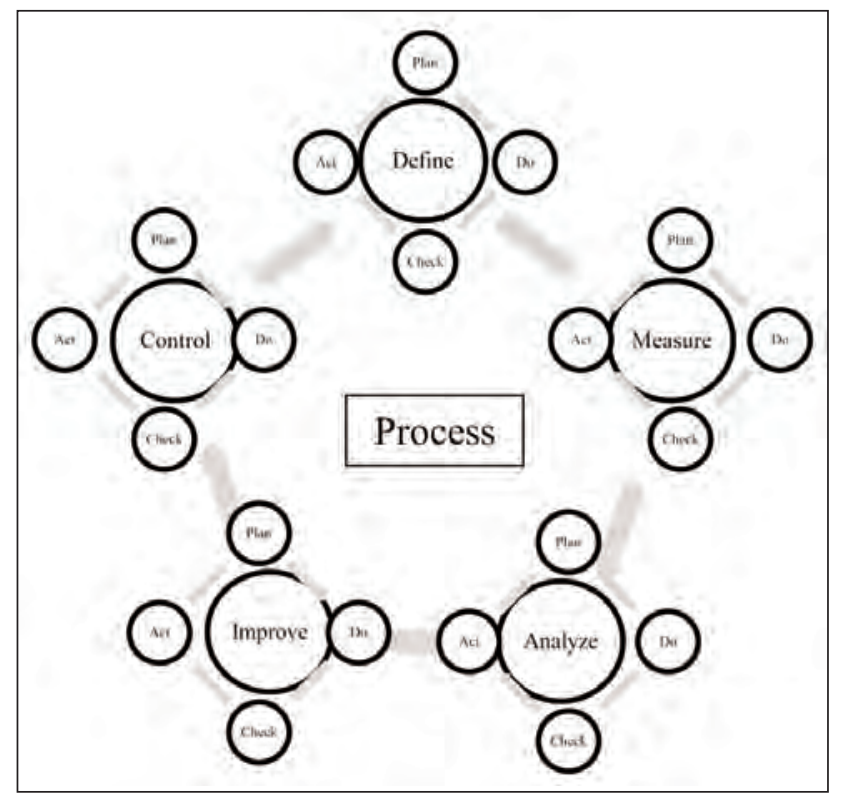

Fig. 1. PDCA-applied-to-DMAIC

\section{RESULTS}

\section{Modeling a LSS methodology}

The developed model uses the technique of integration between DMAIC approach and PDCA cycle. In our work, we have chosen to apply the PDCA cycle to every single step of DMAIC (figure 2). This can improve every sub-system performance and therefore, it can guarantee the success of the complete process. This procedure is applied to all the DMAIC steps, but in our paper we limit to give explanation of Define step. The details of DMAIC structure are given in figure. As it can be seen, the tools and techniques have been integrated into the corresponding DMAIC step. We mentioned that the modeling of the DMAIC 


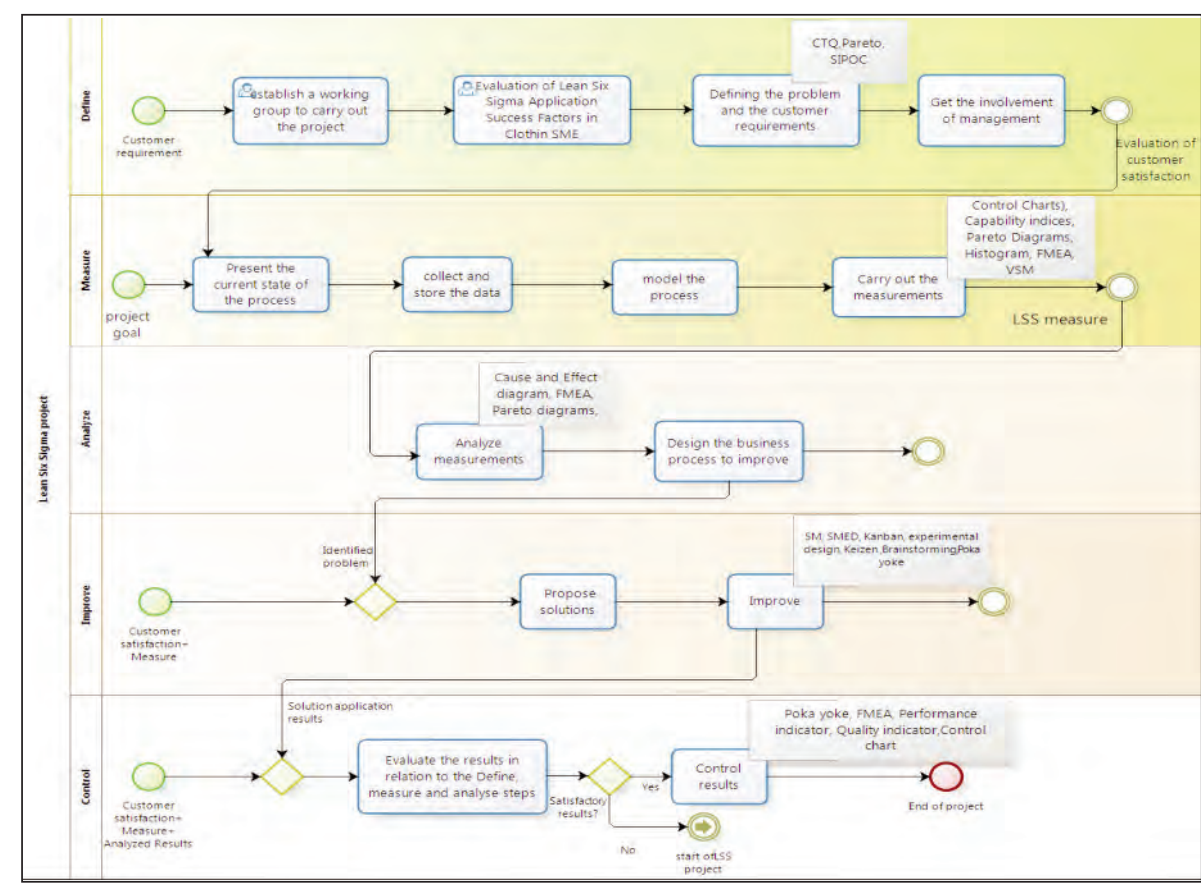

Fig. 2. Modeling a LSS methodology DMAIC steps the importance of and the need for the Lean Six Sigma project and its deliverables. A project schedule SIPOC (Supplier Input Process Output Customer) diagram for the entire loading operation was created in order to provide a clear picture on the suppliers, customers, needed input materials and the sequence of processes involved in manufacturing the product (figure 3).

\section{$>$ The Measure phase:}

In this step, data on measurable indicators of production processes are collected. The objective is to determine the sigma of the process which in turn can give us an idea about the process capability index and approach was carried out using the BPMN standard, because it can give an easy and clear picture of relationship between DMAIC steps.

\section{PDCA Cycle for Define}

Plan:

The objective of the Plan step is to reach the customer satisfaction which represents the main output of Define-step, and to develop its necessary sub-stages.

Do:

The Do step consists in the real implementation of the Plan step.

Check:

In the check step, the customer satisfactions are continuously evaluated, also the success key factors are controlled to prevent any problems and to guarantee the success of Define step.

Act:

In case there is a lack in the required outputs, or any undesirable results, the Act step is applied to fix the problem and to improve the process performances.

\section{Case study}

The study was conducted in a small clothing company specialized in the manufacturing of automotive articles located in Tunisia. The firm is certified with ISO 9001. It interested in improving its sigma level and the customer value.

\section{$>$ The Define phase:}

The initial step in the Define phase consists in forming the team. The project team should be composed by with employees, who are responsible for performing the ship loading process. As management commitment is the most important key of LSS implementation success. A meeting was prepared by the top management in order to explain the employees about

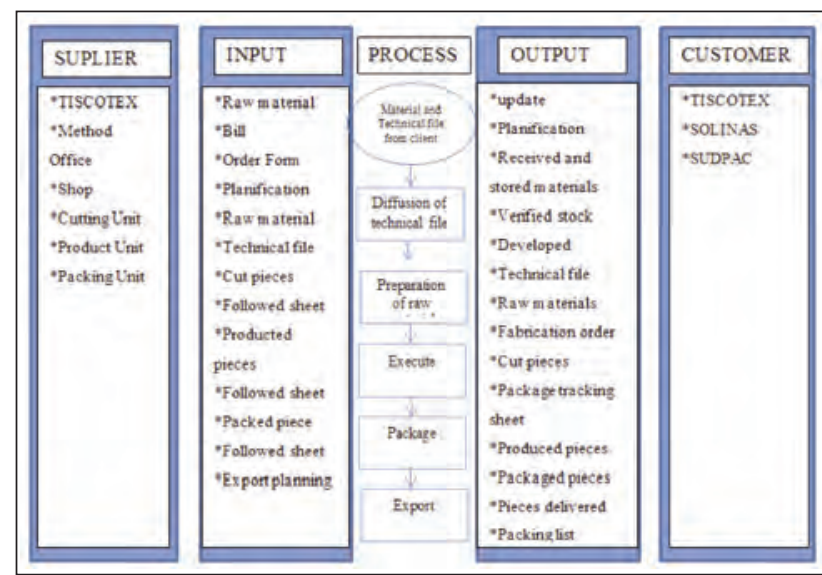

Fig. 3. High level SIPOC diagram of the case study

hence its performances and Identify the types of waste generated by the studied processes.

\section{Process capability Measure}

The analysis of capability is performed to find out actual state of the process]. Once the data are calculated, two sub-processes capability studies are conducted: production and cutting.

The variation for both processes (production and cutting) capability is shown in figures 4 and 5 .

From these figures, we conclude that both processes are incapable, because the $\mathrm{Cp}$ is lower than 1.33. The $Z$ of the complete process is equal to 1.45 .

\section{Process modeling and Simulation}

We propose to show the interest of using the simulation not only to validate the modeling of the process but also to define and position the data acquired to calculate the performance indicators and to test the proposed improvements before implementing them on the actual process of a clothing SME. This modeling and simulation will be done with BPMN standard 


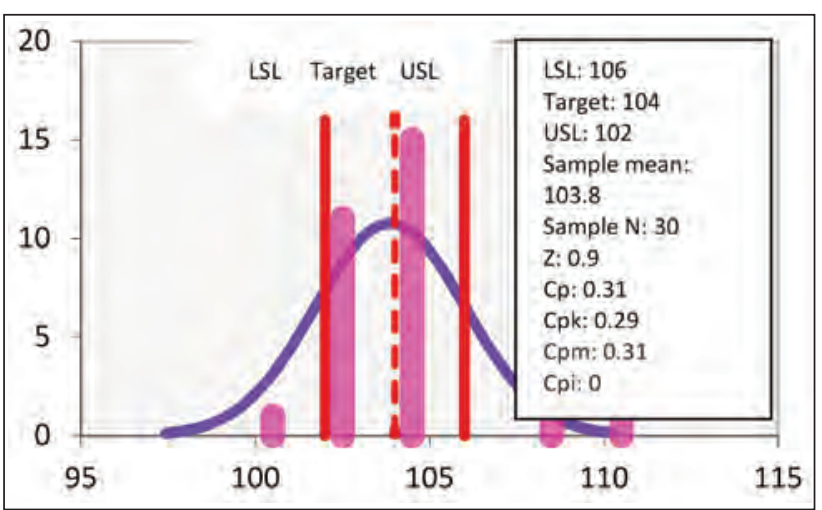

Fig. 4. Process capability of cut sub-process report before improvements implementation

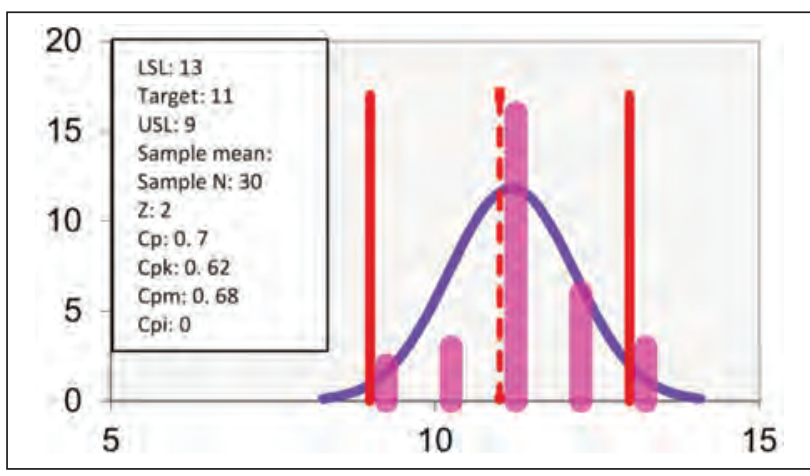

Fig. 5. Process capability of production sub-process report before improvements implementation

using the tool BiZagi (figure 6). Table 1 summarizes the evaluation of performance indicator.

Table 1

EVALUATION OF PERFORMANCE INDICATOR

\begin{tabular}{|l|l|}
\hline \multicolumn{1}{|c|}{ Indicator } & \multicolumn{1}{c|}{ Values } \\
\hline Cycle time & $9 \mathrm{~h} 15 \mathrm{~min}$ \\
\hline Total average waiting time & 8 hour 35 minute 23 s \\
\hline Value added time & 24 min $25 \mathrm{~s}$ \\
\hline Resource utilization & $\begin{array}{l}\text { - Post prepare piece: } 98,9 \% \\
\text { - Post Mount piece: } 41,2 \%\end{array}$ \\
\hline
\end{tabular}

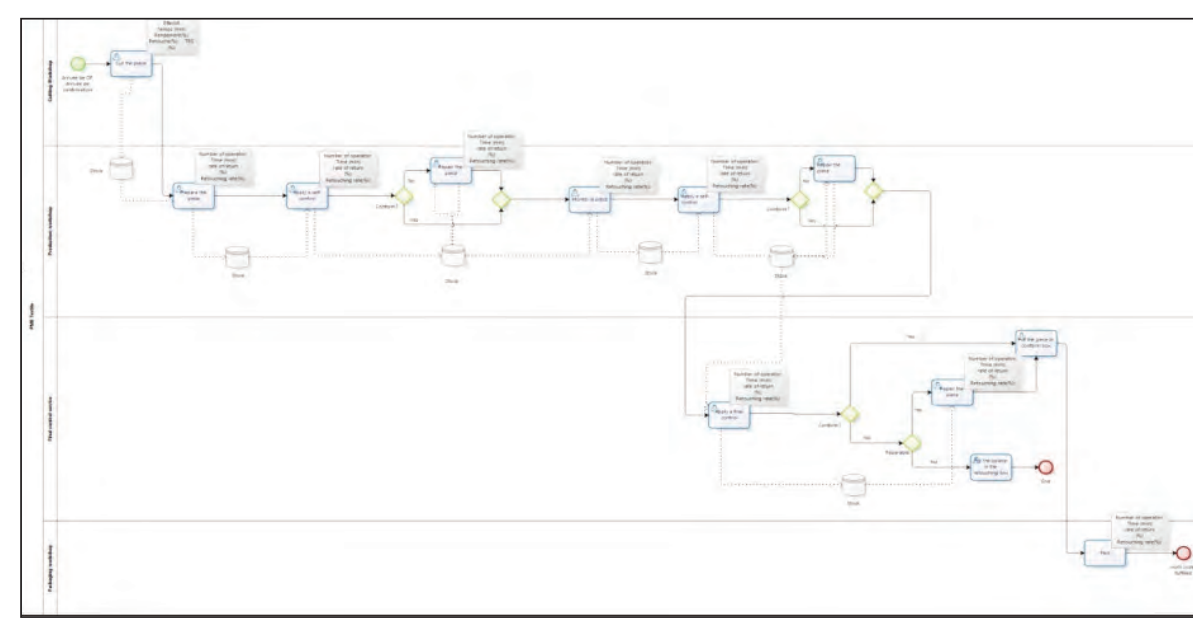

Fig. 6. BPMN diagram model of the sub-processes
Analysis phase:

The analysis phase examines the collected data in order to generate a prioritized list of source of variation in order to identify the root cause and to analyze the problems of process inefficiencies, using the result of the step "Measure". The used tools in our work are the following:

- Identification of failure modes and their causes Based on the available data, the main rejection defects of the product were identified. Seven failure modes that led to the rejection were identified. Table 2 shows the main rejection and their category for the net.

Table 2

\begin{tabular}{|c|c|}
\hline \multicolumn{2}{|c|}{ MAIN REJECTION AND ITS CATEGORY } \\
\hline Defect & Category of defect \\
\hline $\begin{array}{l}\text { The net is assembled in the } \\
\text { wrong position }\end{array}$ & Security defect \\
\hline Incorrect net height & Security defect \\
\hline Incorrect total length & Security defect \\
\hline Low resistance of keder & Security defect \\
\hline Discontinuous stitching & Customer satisfaction \\
\hline Incorrect position of loop & Customer satisfaction \\
\hline Incorrect keder length & Security defect \\
\hline
\end{tabular}

All these defects have effects on user safety, customer satisfaction, or on the installation of the article in the truck. In fact during an accident, the net does not perform its main function of preventing the user from moving forward.

- Root cause analysis

The cause and effect diagram (as shown in figure 7) was drawn to find out the causes of "security defect". Sub-causes were categorized into five general cause categories namely Material, Personnel, Milieu, Methods and Machines.

Cause and effect diagram shows that the most important causes that affect the defect are essentially due to: operator error, bad machine setting, lack of material control at reception, or lack of worker training. We analyzed all other types of defect using the cause-effect diagram

\section{> Improve Phase}

We have concretized the planed actions, respect the deadlines. Since the training and education is among the key factors of success of LSS application, training to the employees involved in implementation of the improvement activities are provided in order to assure the successful implementation. Tools and techniques 5S, Kaizen, Poke yoke and 


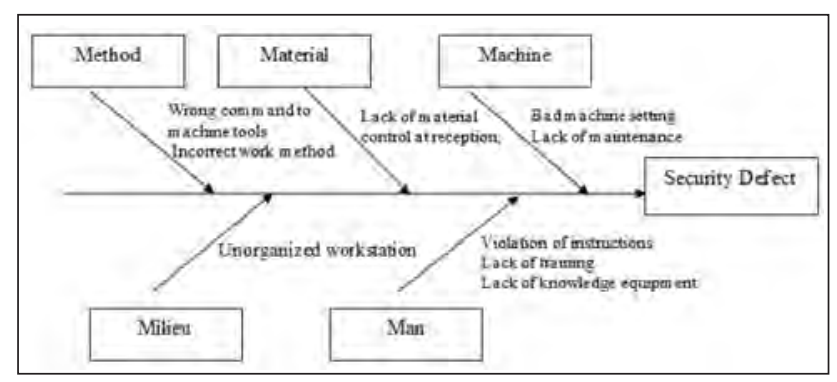

Fig. 7. Cause and effect diagram

other process improvement techniques are applied for planning the improvement activities related to quality and productivity. To validate the obtained results of the improve phase, a confirmatory test was implemented by measuring again process capability and performance indicators.

Table 3

PROPOSED SOLUTION FOR REJECTION DEFECT

\begin{tabular}{|l|l|}
\hline \multicolumn{1}{|c|}{ Defect } & \multicolumn{1}{c|}{ Proposed solution } \\
\hline $\begin{array}{l}\text { The net is assembled } \\
\text { in the wrong position }\end{array}$ & $\begin{array}{l}\text { Construction of a table by } \\
\text { serving Poke yoke }\end{array}$ \\
\hline $\begin{array}{l}\text { Low resistance of } \\
\text { keder }\end{array}$ & $\begin{array}{l}\text { Request to do tests in the } \\
\text { laboratory }\end{array}$ \\
\hline $\begin{array}{l}\text { Discontinuous } \\
\text { stitching }\end{array}$ & $\begin{array}{l}\text { Fixing number of pieces per } \\
\text { bobbin }\end{array}$ \\
\hline $\begin{array}{l}\text { Incorrect position of } \\
\text { loop }\end{array}$ & $\begin{array}{l}\text { Placing two markings on the } \\
\text { table for the loop position }\end{array}$ \\
\hline Incorrect keder length & $\begin{array}{l}\text { Cut the keder in the workshop } \\
\text { Use the lime cutter fixed on the } \\
\text { table } \\
\text { Place a mark on the cutting table }\end{array}$ \\
\hline
\end{tabular}

Table 4

CORRECTIVE ACTIONS FOR EXISTING MUDA TYPE

\begin{tabular}{|l|l|}
\hline \multicolumn{1}{|c|}{ MUDA type } & \multicolumn{1}{c|}{ Corrective actions } \\
\hline $\begin{array}{l}\text { Excessive } \\
\text { displacement }\end{array}$ & $\begin{array}{l}\text { Minimize the displacement by creating } \\
\text { a storage area in the chain }\end{array}$ \\
\hline $\begin{array}{l}\text { Excessive } \\
\text { storage }\end{array}$ & $\begin{array}{l}\text { Minimize the quantity manufactured } \\
\text { per lot }\end{array}$ \\
\hline $\begin{array}{l}\text { Unnecessary } \\
\text { operations }\end{array}$ & $\begin{array}{l}\text { Eliminate intermediate control, Study } \\
\text { and develop key workplace }\end{array}$ \\
\hline
\end{tabular}

Table 3 and 4 show the improvement activities proposed by the team members. Appropriate solutions were provided for each defect and were implemented. $5 S$

Before the application of the improvement project using the 5S method, the key factors of success in order to successfully implement the $5 S$ are fixed.

To reduce the non-value added time for employees, the team starts working on the pillars constituting the $5 S$ method.

\section{Implementation of process Kaizen}

Kaizen Continuous improvement (kaizen) is one of the principle concepts that support the Toyota
Production System (TPS). The kaizen activities were proposed to improvise activity that does not create any value. The kaizen activities were planned such that the overall performance gets improved.

\section{Creation of a facility layout}

We have organized separate standalone workflows after applying operator training to different operations performing in the same cell. The process flow allowed us to identify a waste in terms of transport. In order to optimize the movement between the workstations and the storage areas of raw materials and accessory, we implemented storage area in the workflow. Figures 8 and 9 show the existing layout and the modified layout.

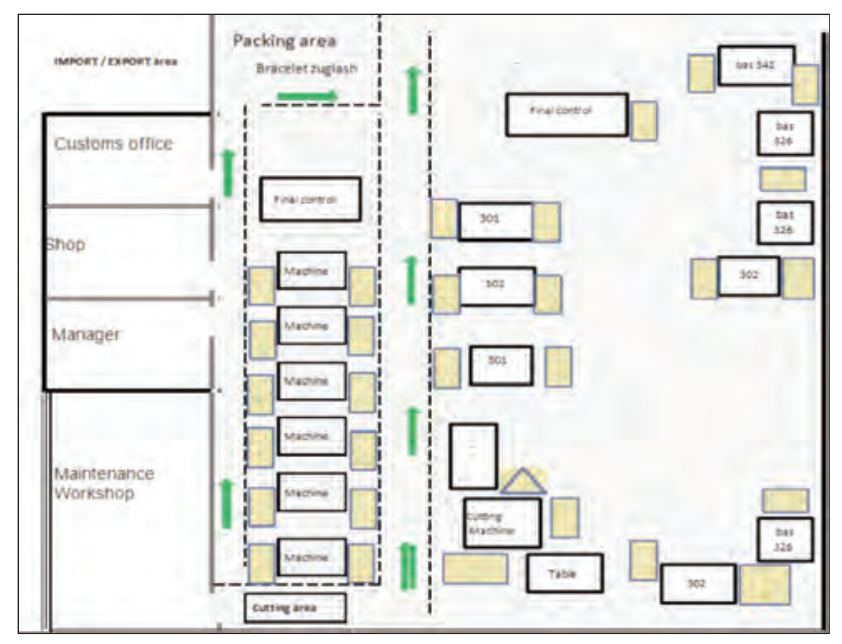

Fig. 8. Existing layout

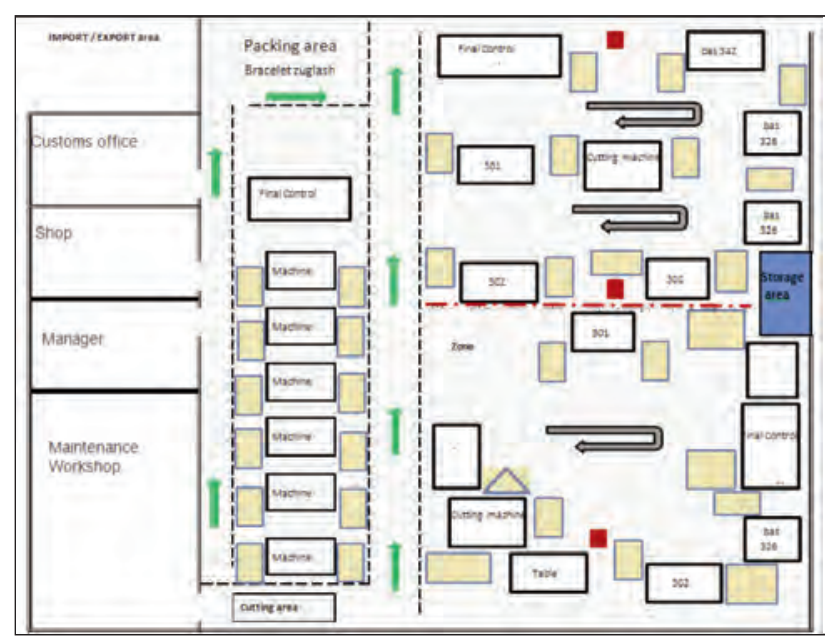

Fig. 9. Modified layout

\section{Validation of best solutions}

In order to validate the obtained results of the improve phase, a confirmatory tests were conducted to validate the modifications. Results showed that after implementing the improvement actions, variation has been decreased consistently and the process is properly centered. Sample of 30 components were taken and were measured in two sub-processes to find its process capability. The process is shifted towards the center mean and it is capable of 


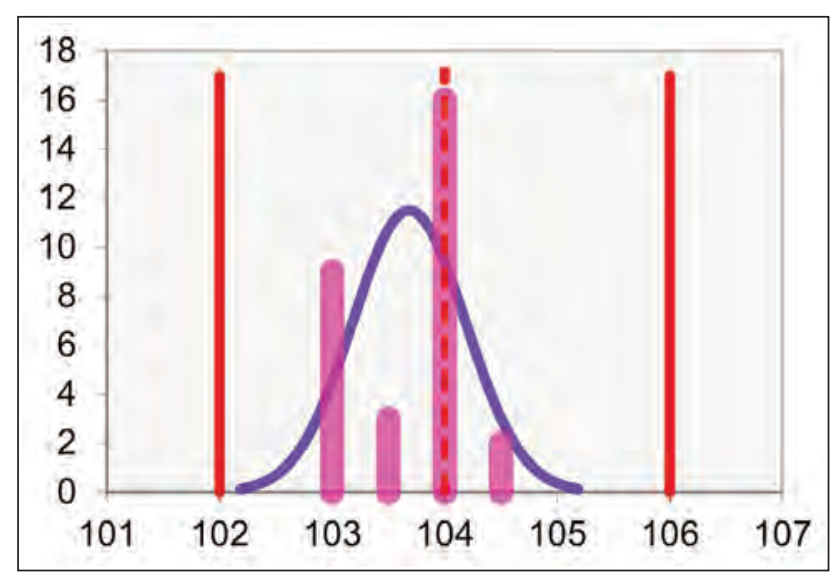

Fig. 10. Process capability of sub-process production report after implementation

Table 5

PROCESS PERFORMANCE INDICATORS BEFORE IMPROVEMENTS

\begin{tabular}{|l|c|c|c|c|c|}
\hline $\begin{array}{c}\text { Sub-pro- } \\
\text { cess }\end{array}$ & $\mathbf{C p}$ & $\mathbf{Z}$ & $\begin{array}{c}\text { Process } \\
\text { capability }\end{array}$ & BPMO & $\begin{array}{c}\mathbf{Z} \\
\text { process }\end{array}$ \\
\cline { 1 - 4 } Cut & 1.3 & 3.89 & Capable & & \\
\cline { 1 - 4 } Production & 1.36 & 4.07 & Capable & & 3.89 \\
\hline
\end{tabular}

producing the components with the specification limits. The obtained process capability for two sub-processes after implementing the improvement actions is shown in figure 10 and figure 11 . Table 5 presents the significant improvements after implementation of Lean Six Sigma methodology of processes.

\section{Control phase}

The applied improvements have been fully integrated into the training regime and the process documentation, the information related to company performance was sharing with its employees. A regular audit of parameters setting was carried out. Visual management, Total Productive Maintenance and Process FMEA are to be implemented after completion of the project to provide a visual aid for controlling the key input and output variables pertaining, and to ensure the team could not revert back to old habits. The control charts are a powerful tool for achieving process control and stability. For this project, the implementation of control charts was important to check that the product meet the desired specifications. Figure 12 shows the control charts for the sub-process cut and sub-process production respectively. We can show the process in general, is in control and stable.

\section{$>$ Evaluation of the PDCA-applied-on-DMAIC}

The DMAIC approach which is applied in certified company is again applied with a non-certified one different in specialization to investigate its effects on the performance of both companies. Table 6 shows the results after improvements of two companies: The key metrics used for comparing the results after

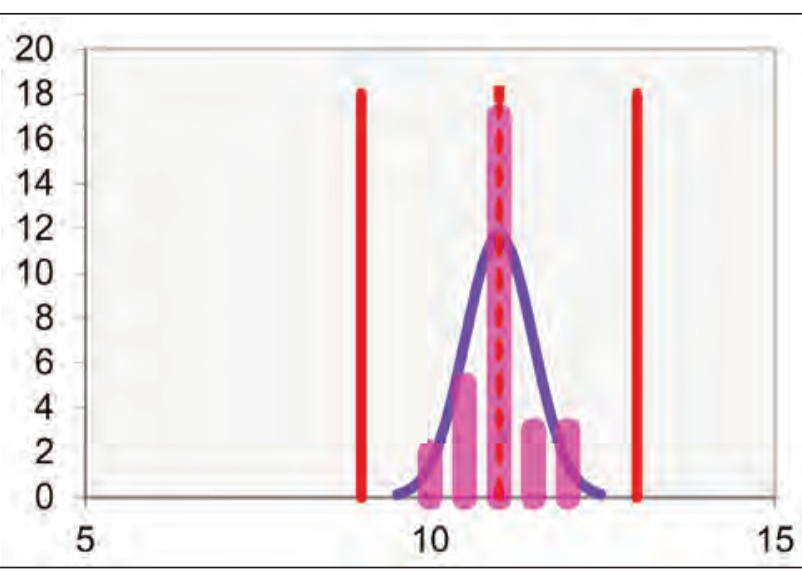

Fig. 11. Process capability of sub-process cut report after implementation

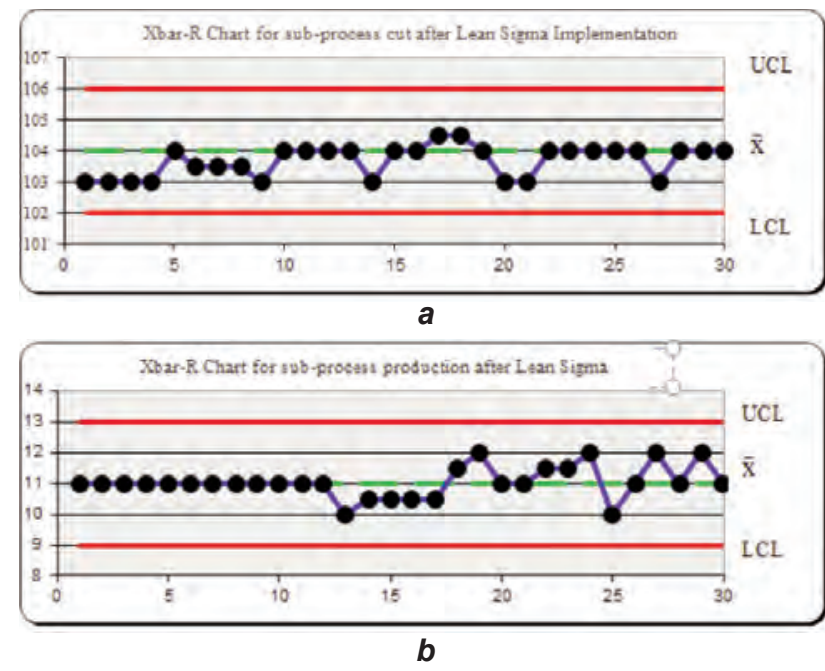

Fig. 12. Control chart of process for (a) sub-process cut and (b) sub-process production

implementing the Lean Six Sigma framework included Z-Sigma, Process Capability Cp, Defects per million opportunities (DPMO), Cycle time and Lead time. The main conclusion that can be summarized from the obtained results and indicators shown in table are:

- The effectives from using PDCA-DMAIC technique are better when it's applied with certified company, than non-certified one. This is because they already applied standards tools of the ISO 9001 witch can help to better use of Lean Six

- The type of produced article has also a considerable effect on the success or not of Lean Six Sigma application, for example security articles recommend some obligation to reduce at a minimum the safety defects.

- The increase of $Z$ in SME specialized in denim articles are not of ease and achievable task because the probability of defects is high.

\section{DISCUSSION}

On completion of this project, we have first concluded that the existing approaches have several limitations and issues, these limitations can be due to a 
RESULTS BEFORE AND AFTER IMPROVEMENTS OF TWO COMPANIES

\begin{tabular}{|l|c|c|c|c|}
\hline \multirow{2}{*}{ Key metrics used } & \multicolumn{2}{|c|}{ Technical articles (Certified ISO 9001) } & \multicolumn{2}{c|}{ Denim articles (Not Certified ISO 9001) } \\
\cline { 2 - 5 } & Before improvements & After improvements & Before improvements & After improvements \\
\hline Z-Sigma & 1.45 & 3.85 & 0.7 & 1.2 \\
\hline Cp & 0.5 & 1.3 & 0.2 & 0.7 \\
\hline DPMO & 540000 & 10700 & 780000 & 308000 \\
\hline Cycle time & 19.92 min & 14.54 min & 12.79 min & 10.1 \\
\hline Lead Time & 39.47 day & 30.23 day & day & 13 day \\
\hline
\end{tabular}

lack in a good comprehension on how to apply the hybrid techniques such as the case of DMAICapplied-to-PDCA. In addition to that, these approaches don't find a real application in our real word which limits its use and the reliability of the given results. On the other side, the new proposed approach has better fundamental basis as it uses the PDCA, which is one of the most effective tool, to continuously improve and control the DMAIC process. In contrast to the existing approaches which have a lack of real application, we have applied this proposed approach to clothing certified SME. The approach also integrate Lean Six Sigma tools and techniques like Kaizen, Pokayoke, Pareto..., and the key factors for LSS success. These tools were determined from survey achieved in a Tunisian clothing sample SMEs and used in every DMAIC step.

The results prove that the proposed approach can be used as an effective and efficient tool to improve process performance. As an example the sigma level was improved from 1.45 to 3.85 . Improvements were observed from I lean metrics such as cycle time and lead time.

Furthermore, the proposed was applied in other noncertified SME producing denim article to investigate the effect of whether the company is certified and the effect of the produced articles on the rate of success of LSS implementation. It was shown that the effectives from using PDCA-DMAIC technique are better when it's applied with certified company, than noncertified one and the type of produced article has also a considerable effect on the success or not of Lean Six Sigma application, for example security articles recommend some obligation to reduce at a minimum the safety defects.

\section{CONCLUSIONS, LIMITATIONS AND FUTURE RESEARCH DIRECTIONS}

This study aims to propose a new Lean Six Sigma (LSS) methodology to improve the process perfor- mances indicators such as $Z$ sigma, $\mathrm{Cp}$, cycle time, and lead time for the case of clothing SME in Tunisia. The methodology is based on combination of two approaches which are the PDCA (Plan, Do, Check, and Act) and the DMAIC (Define, Measure, Analyze, Improve, and Control). Finally, the study is concluded by sorting out the effects of the type of produced articles and the presence or not of the quality certification on the application of the proposed approach.

In our case study, as with our recent work [40], Management commitment and involvement was the most important Critical success factors and the Acceptance of Lean Six Sigma Culture was the most important indicator for implementation of LSS in clothing SME. Although initially, the employees of the studied case believed that the implementation of LSS could affect their performance change their working practices, and eventually endanger their job opportunities. Other major issue was only basic lean tools and techniques had previously been employed (5S, etc.) because of the lack of knowledge about Lean Sigma tools by the employees.

The proposed LSS framework has been test implemented in two Tunisian Textile SMEs, one is certified producing technical article and one non-certified producing denim article, and focused on addressing one specific problem (i.e. defect). In the future, this framework can be used as a base and adapted to drive improvements in other textile SMEs and to hold other operational problems. In addition, more tools and techniques can be added, or removed, from the framework for specific adaptation and improvement.

\section{ACKNOWLEDGEMENTS}

We would like to thank the director of the company in which we applied our work.

\section{REFERENCES}

[1] Laureani, A., Antony, J., Critical success factors for the effective implementation of Lean Sigma: Results from an empirical study and agenda for future research, In: International Journal of Lean Six Sigma, 2012, 3, 4, 274-283

[2] Peteros, R.G., Maleyeff, J., Using Lean Six Sigma to improve investment behavior, In: International Journal of Lean Six Sigma, 2015, 6, 1, 59-72 
[3] Darshak, A., Desai, Antony, J., Patel, M.B., An assessment of the critical success factors for Six Sigma implementation in Indian industries, In: International Journal of Productivity and Performance Management, 2012, $61,4,426-444$

[4] Basant, C., Dixit, G., Ashish, A., Framework to improve performance through implementing Lean Six Sigma strategies to oil exporting countries during recession or depression, In: International Journal of Productivity and Performance Management, 2016, 65, 3, 422-432

[5] Ang, Boon, Sin, Suhaiza, Z., Mohammad, I., Ramayah, T., Structural Equation Modelling on Knowledge Creation in Six Sigma DMAIC Project and Its Impact on Organizational Performance, In: Int. J. Production Economics, 2016, 168, 105-117

[6] Vijaya, Sunder, M., Rejects reduction in a retail bank using Lean Six Sigma, In: Production Planning \& Control, 2016, 27, 14, 1-12

[7] Gijo, E.V., Antony, J., Kumar, M., McAdam, R., Hernandez, J., An application of Six Sigma methodology for improving the first pass yield of a grinding process, In: Journal of Manufacturing Technology Management, 2014, 25, 1, 125-135

[8] Ben Ruben, R., Vinodh, S., Asokan, P., Implementation of Lean Six Sigma framework with environmental considerations in an Indian automotive component manufacturing firm: a case study, In: Production Planning \& Control, 2017, 28, 15, 1-19

[9] Krueger, D.C., Parast, M.M., Adam, S., Six Sigma Implementation: A Qualitative Case Study Using Grounded Theory, In: Production, Planning \& Control, 2014, 25, 10, 873-889

[10] Timans, W., Antony, J., Ahaus, K., Van Solingen, R., Implementation of Lean Six Sigma in small-and medium-sized manufacturing enterprises in the Netherlands, In: Journal of the Operational Research Society, 2012, 63, 3, 339-353

[11] Anderson, N.C., Kovach, J.V., Reducing welding defects in turnaround projects: A Lean Six Sigma case study, In: Quality Engineering, 2014, 26, 2, 168-181

[12] Kumar, M., Antony, J., Singh, R.K., Tiwari, M.K., Perry, D., Implementing the Lean Sigma framework in an Indian SME: a case study, In: Production Planning \& Control, 2006, 17, 4, 407-423

[13] Sunder, V., Antony, J., Six-sigma for Improving Top-box Customer Satisfaction Score for a Banking Call Centre, In: Production, Planning \& Control, 2015, 26, 16, 1291-1305

[14] Vijaya, Sunder, M., Rejects reduction in a retail bank using Lean Six Sigma, In: Production Planning \& Control, 2016, 27, 14, 1-12

[15] Garza-Reyes, J.A., Al-Balushi, M., Anthony, J., Kumar, V., A Lean Six Sigma framework for the reduction of ship loading commercial time in the iron ore pelletising industry, In: Production Planning \& Control, 2016, 27, 3, 1092-1111

[16] Hicks, C., McGovern, T., Prior, G., Smith, I., Applying Lean Principles to the Design of Healthcare Facilities, In: International Journal of Production Economics, 2015, 170, 677-686

[17] Sadraoui, T., Fayza, J., Efficacité de la Méthodologie Six Sigma dans la Gestion de la Chaine Logistique, In: International Journal of Econometrics and Financial Management, 2014, 2, 6, 220-235

[18] Sokovic, M., Pavletic, D., Kern Pipan, K., Quality improvement methodologies - PDCA Cycle, RADAR Matrix, DMAIC and DFSS, In: Journal of achievements materials and Manufacturing Engineering, 2010, 43, 1, 476-483

[19] Mili, K., Sadraoui, T., Six Sigma Approach for the Straddle Carrier Routing Problem, In: International Journal of Econometrics and Financial Management, 2014, 2, 1, 34-47, http://doi.org/10.12691/ijefm-2-1-5

[20] Timans, W., Ahaus, K., Antony, J., Six Sigma methods applied in an injection mouldingcompany, In: International Journal of Lean Six Sigma, 2014, 5, 2, 149-167

[21] Manville, G., Greatbanks, R., Krishnasamy, R., Parker, D.W., Critical success factors for Lean Six Sigma programmes: a view from middle management, In: International Journal of Quality \& Reliability Management, 2012, 29, 1, 7-20

[22] Karthi, S., Devadasan, S.R., Selvaraju, K., Sivaram, N.M., Sreenivasa, C.G., Implementation of Lean Six Sigma through ISO 9001:2008 based QMS: a case study in a textile mill, In: Journal of The Textile Institute, 2013, 104, 10, 1089-1100

[23] Dede, Adikorley, R., Rothenberg, L., Lean Six Sigma applications in the textile industry: a case study, In: International Journal of Lean Six Sigma, 2016, 8, 2, 210-224

[24] George, D., Mallery, P., SPSS for Windows step by step: A simple guide and reference, 11.0 update (fourth Ed.), 2003, Boston: Allyn \& Bacon

[25] Das, P., Roy, S., Antony, J., An application of Six Sigma methodology to reduce lot-to-lot shade variation of linen fabrics, In: Journal of Industrial Textiles, 2007, 36, 227-251

[26] Sadraoui, T., Ghorbel, A., Design process improvement through DMAIC Sigma approach: A wood consumption case study, In: International Journal of Productivity and Quality Management, 2011, 7, 2, 229-262

[27] Tudor, L., Change in Textile and Clothing Industry, In: Industria Textila, 2018, 69, 1, 37-42, http://doi.org/ 10.35530/IT.069.01.1449

[28] Cudney, E.A., Furterer, S., Dietrich, D., Lean Systems: Applications and Case Studies in Manufacturing, Service, and Healthcare, Boca Raton, 2013, FL: CRC Press 
[29] Voehl, F., et al., The Lean Six Sigma Black Belt Handbook: Tools and Methods for Process Acceleration, CRC Press, Boca Raton, In: American Journal of Operations Research, 2013, 5, 3

[30] Garza-Reyes, J. A., Flint, A., Kumar, V., Antony, J., Soriano-Meier, H., A DMAIRC Approach to Lead Time Reduction in an Aerospace Engine Assembly Process, In: Journal of Manufacturing Technology Management, 2014, 25, 1, 27-48

[31] Zhang, M., Wang, W., Goh, T.N., He, T., Comprehensive Six Sigma Application: A Case Study, In: Production, Planning \& Control, 2015, 26, 3, 219-234

[32] Vinodh, S., Kumar, S.V., Vimal, K.E.K., Implementing Lean Sigma in an Indian Rotary Switches Manufacturing organization, In: Production Planning \& Control, 2014, 25, 4, 288-302

[33] Thomas, J., Francis, M., Fisher, R., Byard, P., Implementing Lean Six Sigma to overcome the production challenges in an aerospace company, In: Production Planning \& Control, 2016, 27, 7-8, 1-13

[34] Garza-Reyes, J.A., Al-Balushi A., Antony, J, Kumar, V., A Lean Six Sigma framework for the reduction of ship loading commercial time in the iron ore pelletising industry, In: Production Planning \& Control, 2016, 27, 13, 1-20

[35] Sushovan, G., Maiti, J., Data mining driven DMAIC framework for improving foundry quality - a case study, In: Production Planning \& Control, 2014, 25, 6, 478-493

[36] Saja, A.A, Antony, J., Abdul halim Lim, S., A systematic review of Lean Six Sigma for the manufacturing industry, In: Business Process Management Journal, 2015, 21, 3, 665-691

[37] Jones, E.C., Parast M.M., Adams, S.G., A framework for effective Six Sigma implementation, In: Total Quality Management \& Business Excellence, 2010, 21, 4, 415-424

[38] Drohomeretski, E., Gouvea da Costa, S.E., Pinheiro de Lima, E., Da Rosa Garbuio, P.A., Lean, Six Sigma and Lean Six Sigma: an analysis based on operations strategy, In: Production Planning \& Control, 2014, 52, 3, 804-824

[39] Kumar, M., Critical Success Factors and Hurdles to Six Sigma Implementation: The Case of a UK Manufacturing SME, In: International Journal of Six Sigma and Competitive Advantage, 2007, 3, 4, 333-351

[40] Nedra, A., Néjib, S., Yassine, CH., Morched, CH., Critical success factors of Lean Six Sigma implementations within small and medium Tunisian clothing industries, In: International Conference of Applied Research on Textile, CIRAT7, 2016, Hammamet, Tunisia

[41] Taner, M.T., Critical Success Factors for Six Sigma Implementation in Large-scale Turkish Construction Companies, In: International Review of Management and Marketing, 2013, 3, 4, 212-225

[42] Lupan, R., Bacivarof, I.C., Kobi, A., Robledo, C., A relationship between Six Sigma and ISO 9000:2000, In: Quality Engineering, 2005, 17, 4, 719-725

[43] Jones, E.C., Parast, M.M., Adams, S.G., A framework for effective Six Sigma implementation, In: Total Quality Management \& Business Excellence, 2010, 21, 4, 415-424

\section{Authors:}

ABBES NEDRA, SEJRI NÉJIB, CHAABOUNI YASSINE, CHEIKHROUHOU MORCHED

Textile Engineering Laboratory (LGTEX), Higher Institute of Technical Studies of ksarhellal (ISET),

Monastir University, Tunisia

Corresponding author:

ABBES NEDRA

e-mail: Nedraabbes2@gmail.com 